\author{
光学ガラスによる誘導ブリルアン散乱位相共役波の発生 \\ 吉田 英次, 藤田 尚徳, 中塚 正大, 吉田 國雄 * \\ 大阪大学レーザー核融合研究センター (テ565-0871 大阪府吹田市山田丘2-6) \\ *大阪工業大学電子工学科（干535-8585 大阪市旭区大宮5-16-1）
}

\title{
Generation of Stimulated Brillouin Scattering Phase-Conjugated Wave Using Optical Glasses
}

\author{
Hidetsugu YOSHIDA, Hisanori FUJITA, Masahiro NAKATSUKA, and Kunio YOSHIDA* \\ Institute of Laser Engineering, Osaka University, 2-6 Yamada-oka, Suita, Osaka 565-0871 \\ ${ }^{*}$ Department of Electronic Engineering, Osaka Institute of Technology \\ 5-16-1 Ohmiya, Asahi-ku, Osaka 535-8585
}

(Received February 4, 1999)

\begin{abstract}
Stimulated Brillouin scattering (SBS) reflectivity and gain coefficient of bulk optical glasses, a laser glass and a fused-silica glass are measured at wavelength of $1.06 \mu \mathrm{m}$. The reason why optical glass has a high damage threshold at long Q-switched pulse operation is explained in terms of the SBS backward reflectance. A flint glass of SF-6 has high SBS gain compared with the gaseous or liquid materials. Fused-silica glasses are most promissing as a phase conjugated SBS mirror for all solid-state high-energy lasers because of high damage threshold and their low absorbance.
\end{abstract}

Key Words: Optical glass, Phase conjugation, Stimulated Brillouin Scattering, Nonlinear refractive index, Laser-induced damage

1. はじめに

固体媒質を用いた位相共役波の発生方法には, 主に誘導 散乱 1 )やフォトリフラクティブ効果2)等があり, 我々は高繰 り返し, 高出力固体レーザーの波面補正方法として, 誘導 ブリルアン散乱 (以下SBS) ${ }^{3-5}$ )による位相共役鏡を検討し てきた.この特性を利用すれば,レーザー光が光学的に不 均質な媒質を伝搬する場合に発生する波面収差を同一路 の逆進行により補正できるため, 画期的かつ簡便である. この方法は, 高出力レーザー増幅器で誘起される波面の乱 れの補正6-10)やマルチモードファイバ画像処理におけるひ ずみ補正11)等への応用が期待されている.

SBS位相共役鏡として研究されている主な媒質 ${ }^{12)}$ は, 気 体, 液体が中心であり, 固体媒質の研究はブリルアン散乱 の分光研究による物性值評価例13) はあるが, 位相共役鏡と しての研究はあまりなされていない. 我々は, 固体媒質と して初めて, 取り扱いが簡単で, 小型, 高感度, 高いレーザー 耐力を持つLアルギニンリン酸(LAP) 有機結晶を用いた SBS位相共役鏡を見い出した14-15)。しかしながら, LAP結 晶の大型化は困難であるため, 入射レーザー強度が限定さ れる。また，高価であるため，損傷の発生を考えた場合不 向きである. 一方, 光学ガラスは結晶に比べ安価, 入手が 容易であり, 比較的高品質で大型形状まで加工可能であ る. また, 光学ガラス材料のSBS利得係数の測定により,大
型レーザーに使用される大口径光学素子(空, レンズ等)の SBS損失を推測できる.

ガスや液体を用いる場合, 実際的なレーザーエネルギー の上限は媒質中の不純物で決まっており, 容器の洗浄技術 や媒質の高精度乃過技術等が必要とされる。固体は高品 質な材料を選択すればよい. また, ガスや液体は, 高い励 起入力時において媒質の吸収により集光領域が加熱され る.このため, 集光領域とそのまわりの温度差により対流 が発生し, SBS特性が低下する ${ }^{16)}$ 。一方, 固体での温度分布 の発生は位相共役鏡として補償するため問題とならな い. しかし,ガスや液体に比べ, LAP結晶以外の固体材料の SBS利得係数は一般的に小さい. また, 固体材料の問題点 は, レーザー損傷が発生すると使用できなくなるため, 励 起入力エネルギーが制限されることである.

本報告では, 非晶質光学ガラスのSBS利得係数, SBS特性 およびレーザー損傷しきい值とSBS発生しきい值の関係を 測定した. また,これら光学ガラスを用いたSBS位相共役 鏡としての入射可能なエネルギーについて議論した。

\section{2. 光学ガラスの SBS 反射特性とレーザー損傷}

\section{1 実験方法}

固体は一度ダメージが発生すると使用することが困難 となるため, 使用する媒質のレーザー耐力とSBS発生の関 
係を十分把握することにより,初めて使用可能となる.

測定した光学ガラスはフリント (Flint) 系ガラス 5 種類 (LF-1, LF-5, LLF-1, KF-6とSF-6), クラウン (Crown)系ガラ ス3種類 (BK-7, BK-7W とFK-5), レーザーガラス (LG-760) と溶融石英ガラスの 10 種類である。測定試料の大きさは $25 \times 25 \times 30 \mathrm{~mm}$ である。

SBS反射率特性およびレーザー損傷しきい值測定配置図 をFig.1に示す。単一縦モードQスイッチYAGレーザー(波 長1.06 $\mu \mathrm{m}$, パルス幅 $1.1 \mathrm{~ns}$ と $25 \mathrm{~ns}$ ) は, 焦点距離 $f=100 \mathrm{~mm}$ の 単レンズを用いて集光される．入出射面は, 表面損傷を考 慮して反射防止膜は施さず, 表面から約 $25 \mathrm{~mm}$ の位置に集 光した.このときの集光スポット径は約 $150 \mu \mathrm{m}$ である.

SBS反射率特性は通常の高反射率鏡の反射率 $99.8 \%$ を参 照值とし, 光学ガラス試料の入反射波形掞よび透過波形か ら測定した。また,サンプル有無時のエネルギー透過率か らも求めた．ガラス内部のレーザー損傷しきい值は, 入射 パルス幅1.1nsの場合, SBS発生を抑制するためSBS反射波 が発生しきい值に到達する時間(光学ガラスの音響緩和時 間約4〜 6ns)より速い立ち上がりパルス $(0.5 \mathrm{~ns})$ を入射する ことにより,真の内部損傷しきい值を測定した。パルス幅 25nsの場合は, サンプルのSBS反射率を考慮し, 透過エネル ギー強度から真の内部損傷しきい值を求めた。

\subsection{SBS反射率特性}

SBS特性を測定した光学ガラスは, アッベ数 $v$ よって, $v$ $>55$ をラウン系ガラス, $v<50$ をリント系ガラスとに 分類される．クラウン系ガラスであるBKおよびFK系は アッべ数が大きく, 屈折率1.5(可視域) 前後のガラスであ る. 特にBK-7はレーザー用光学部品に最も広く利用さ れ,かつ多量に生産されている高品質材料である。一方, フ リント系ガラスはアッベ数の減少によってSFからF, LF, LLF, KF系へと変化する. SF-6はアッべ数約 27 , 屈折率 1.75 であり,波長分散用プリズムとして広く利用されている.

パルス幅 $25 \mathrm{~ns}$ のレーザー光を各種光学ガラスに入射した 時, 入射エネルギーに対するSBS反射率特性結果をFig.2 (a) フリント系光学ガラス, (b) クラウン系光学ガラス, レー ザーガラスおよび石英ガラス,に示す，図において大きい 丸印は,レーザー損傷が発生したことを示す. Fig.2 (a)に おいて, SF-6のSBS反射しきい值は約 $5 \mathrm{~mJ} ゙$ あり, 測定サン

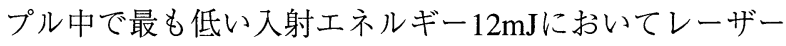
損傷が発生し, その時のSBS反射率は32\%であった. LF-1, LF-5のSBS発生しきい值は9mJであり, 入射エネルギー33〜

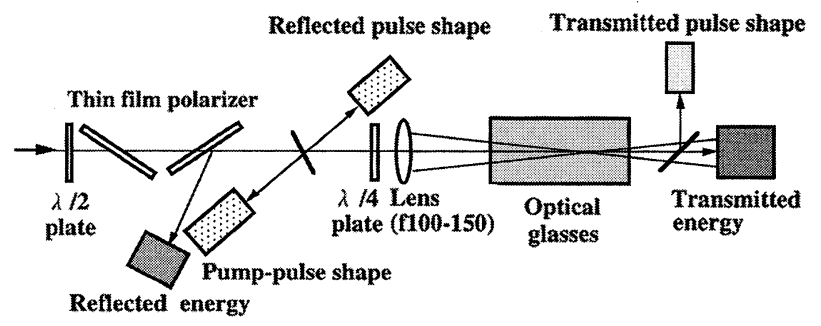

Fig.1 Schematic of the arrangement for observation of phase-conjugation by stimulated Brillouin scattering.

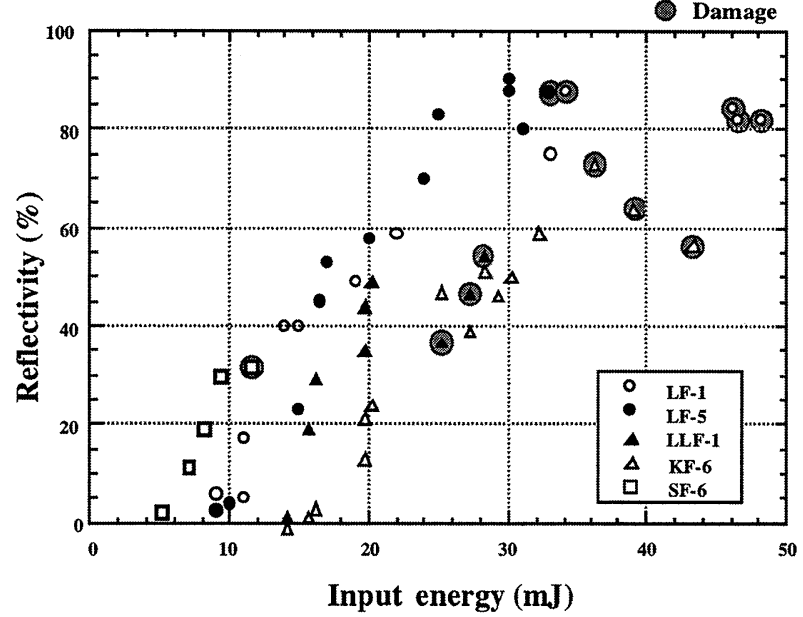

(a)

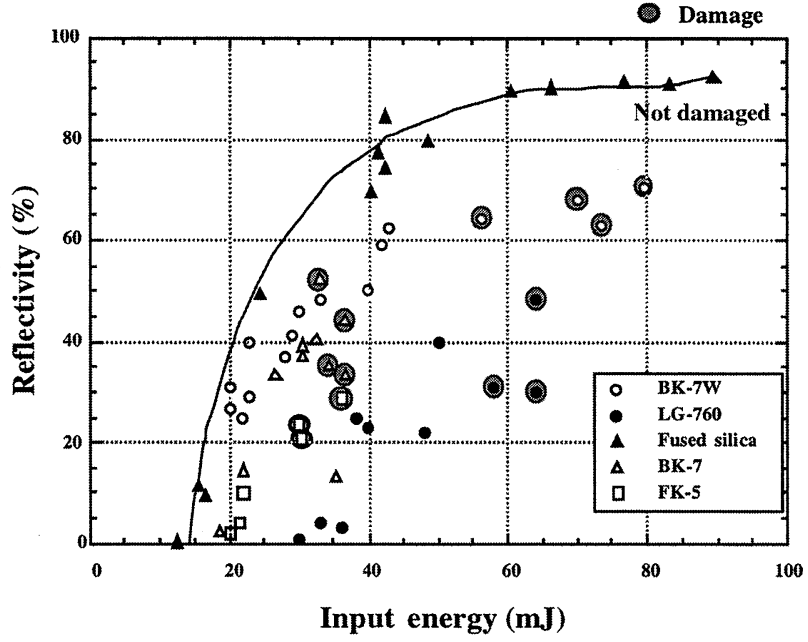

(b)

Fig.2 The SBS reflectivity of optical glasses as a function of input energy at pulse width of $25 \mathrm{~ns}$; (a) Crown glasses, (b) Flint glasses, fused-silica and laser glass.

$34 \mathrm{~mJ}$ の時最大反射率90\%が得られた．SF-6を除くフリン ト系ガラスはSBS反射率80\%以上が得られた。一方, Fig.2 (b)において,クラウン系ガラスのSBS発生しきい值は $20 \mathrm{~mJ}$ 〜30mJであり,フリント系に比べ約2３倍高い. 例えば, BK-7は発生しきい值 $20 \mathrm{~mJ}$, 入射エネルギー $30 \mathrm{~mJ}$ の時SBS反 射率40\%が得られたが, 30mJ上では損傷が発生した。リ ン酸系レーザーガラスLG-760は入射エネルギー45mJ以上 の時最大反射率 $60 \%$ が得られた. 石英ガラスはSBS発生し きい值 $15 \mathrm{~mJ}$, 入射エネルギー $90 \mathrm{~mJ}$ の時最大反射率 $90 \%$ が得 られた，石英ガラスの場合, 入射エネルギーは入射表面の 損傷によって制限され, 石英ガラスの内部損傷は発生しな かった。

\section{3 光学ガラスのSBS物理定数 (SBS利得係数)}

各光学ガラスのSBS利得係数は, 理論式とSBS発生しき い值から求めた。各光学ガラスの理論的SBS利得係数 $g_{\mathrm{B}}$ は, 材料の物理定数から, 以下のように表される17,18).

$$
g_{\mathrm{B}}=\frac{2 \pi \cdot n^{7} \cdot P_{12}^{2}}{c \cdot \rho \cdot V \cdot \Delta v_{\mathrm{B}}} \cdot \frac{1}{\lambda^{2}}
$$


ここで, $n$ は光学ガラスの励起波長での屈折率, $P_{12}$ は電気光 学定数, $c$ は光速, $\rho$ は密度, $V$ はガラスの音速, $\Delta v_{\mathrm{B}}$ はガラス のブリルアン散乱のスペクトル幅と入は入射レーザー波長 である. (1)式より, 屈折率と電気光学定数の大きい材料, 例えばフリント系ガラスは高いSBS利得係数 $g_{\mathrm{B}}$ を持つ.

実験的に定常状態でのSBS利得係数を測定する場合, 物 質の音響緩和時間の約10倍以上のパルス幅のレーザー光 を使用して,SBS発生しきい値エネルギーから求める。例

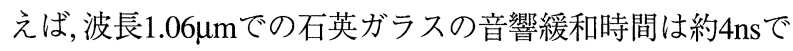
あり, 約40ns以上のパルス幅で励起する必要がある。しか しながら,測定したパルス幅は約25nsであるため, 過渡状態 でのSBS発生しきい值から定常状態でのSBS利得係数を (2)式より求めた19).

$$
g_{\mathrm{Bexp}}=\lambda \frac{\left(15 \tau_{\mathrm{B}}+t\right)^{2}}{2 m E_{\mathrm{th}}}
$$

ここで $E_{\mathrm{th}}$ はSBS発生しきい値エネルギー, $t$ はパルス幅, $\tau_{\mathrm{B}}$ は物質の音響緩和時間である。また, $m$ はSBSのノイズ発生 しきい值ファクターで0.9から1である.

各光学ガラスのSBS利得係数の計算結果㧍よび実験結果 をTable1に示す。（1)式より求めた溶融石英ガラスのSBS 利得係数は $2.8 \mathrm{~cm} / \mathrm{GW}$ が得られ, (2) 式のSBS発生しきい值 より求めた定常状態のSBS利得係数は $3.4 \mathrm{~cm} / \mathrm{GW}$ となり,ほ ほ一致した。クラウン系光学ガラスは $3 \mathrm{~cm} / \mathrm{GW}$ 程度であ る. 一方, フリント系光学ガラスのSBS利得係数はLF-1, 5 では約 $6 \mathrm{~cm} / \mathrm{GW}$ である. 測定材料中最も小さいSBS発生し きい値を示したSF-6は約 $9.3 \mathrm{~cm} / \mathrm{GW}$ となり,計算值 $9.7 \mathrm{~cm} /$ GWとほぼ一致した。よって, SF-6は石英ガラスやクラウ ン系ガラスに比べ, 約 3 倍以上のSBS利得係数であり, 液体 媒質と同等である.

光学ガラスの非線形屈折率とSBS発生しきい值の関係に ついて調べた. 光学ガラスの非線形屈折率 $n_{2}$ は,

$$
n_{2}=\left(12 \pi / n_{0}\right) \chi^{3}
$$

であり,三次の非線形感受率 $\chi_{3}$ に比例する. $\chi_{3}$ はSBS利得 係数 $g_{\mathrm{B}}$ と等価であることから, $n_{2}$ の大きい光学ガラスは SBS利得係数が大きい. Fig.3は各光学ガラスの非線形屈折 率 $n_{2}$ とSBS発生しきい值パワー $P_{\mathrm{th}}$ 扰よびSBS利得係数 $g_{\mathrm{B}}$ の 関係を示す．実験結果より求めた経験式を(4)式に示す.

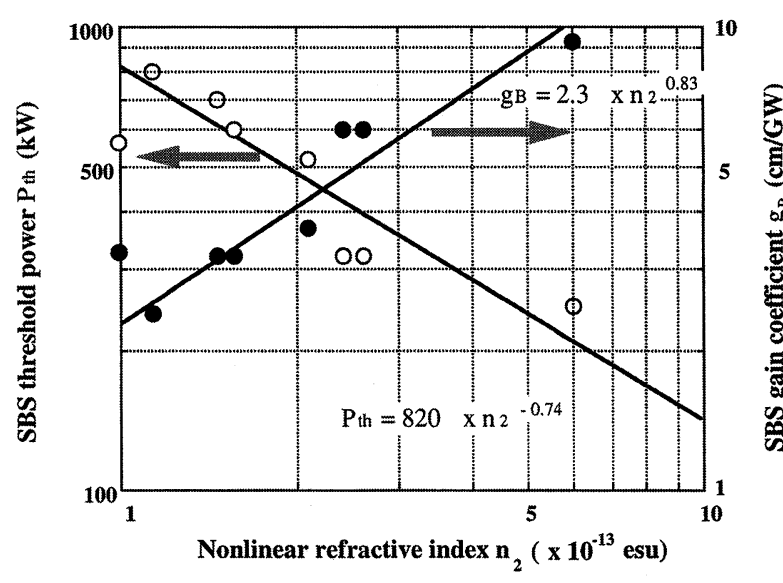

Fig.3 SBS threshold power and SBS gain coefficient as a function of nonlinear refractive index for optical glasses.

$$
\begin{array}{ll}
P_{\mathrm{th}}=(820 \pm 100) \cdot n_{2}^{-0.74} & (\mathrm{~kW}) \\
g_{\mathrm{B}}=(2.3 \pm 0.6) \cdot n_{2}^{0.83} & (\mathrm{~cm} / \mathrm{GW})
\end{array}
$$

よって, $n_{2}$ の大きい光学ガラスを選択することにより,低 いSBS発生しきい值の固体材料が期待できる. しかしなが ら, 2.4 節で述べるように, $n_{2}$ の大きい光学ガラスはレーザー 耐力が小さいため, 集光条件や入射エネルギー等に注意し なければならない。

\section{4 レーザー損傷しきい值測定}

2種類のパルス幅 $(1.1 \mathrm{~ns}$ と $25 \mathrm{~ns})$ について, 各種光学ガラス のレーザー損傷しきい值測定結果をTable 2 に示す。パルス 幅1.1nsの内部損傷は, 石英ガラスおよびBK-7, FK-5等のク ラウン系は $28 \pm 3 \mathrm{~J} / \mathrm{cm}^{2}$ 前後であったが, フリント系LF-1, 5 は $15 \pm 2 \mathrm{~J} / \mathrm{cm}^{2}, \mathrm{SF}-6$ は $8 \pm 1 \mathrm{~J} / \mathrm{cm}^{2}$ であり,クラウン系に比べ 低いレーザー耐力を示した。

次に, $25 \mathrm{~ns}$ パルスでの内部損傷は, SBSの反射率と内部吸 収損失を考慮して損傷しきい值を求めた，すなわち, 集光 時に光学ガラス中の焦点位置を透過するエネルギーより 求めた。 BK-7の場合, 損傷が発生した入射エネルギーは $33 \mathrm{~mJ}$ あ゙り, SBS反射率約40～55\%を考慮するとガラス内

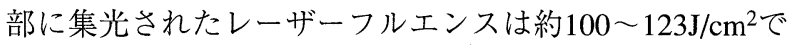

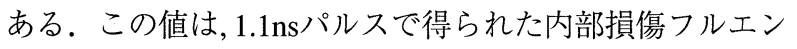

Table 1 SBS steady-state gain coefficient of optical glasses.

\begin{tabular}{cccccc}
\hline \hline Materials & $\begin{array}{c}\text { Nonlinear } \\
\text { refractive index } \\
n_{2}\left(\times 10^{-13} \mathrm{esu}\right)\end{array}$ & $\begin{array}{c}\text { SBS threshold } \\
\text { power } P_{\text {th }} \\
(\mathrm{kW})\end{array}$ & \multicolumn{2}{c}{ SBS gain coefficient $g_{\mathrm{B}}(\mathrm{cm} / \mathrm{GW})$} \\
\hline FK-5 & 1.13 & 800 & 1.7 & 2.4 & Calculated \\
BK-7 & 1.46 & 700 & 2.5 & 3.2 & 2.1 \\
KF-6 & 1.56 & 600 & & 3.2 & \\
LF-1 & 2.5 & 320 & & 6.0 & \\
LF-2 & 2.6 & 320 & & 6.0 & \\
LLF-1 & 2.1 & 520 & & 3.7 & \\
SF-6 & 5.9 & 250 & 9.7 & 9.3 & \\
\hline Fused-silica & 0.99 & 650 & 2.8 & 3.4 & 3.0 \\
LG-760 & 1.0 & 1200 & & 1.6 & \\
\hline \hline
\end{tabular}


Table 2 Laser indued damage threshold of several optical glasses.

\begin{tabular}{|c|c|c|c|c|c|c|c|c|}
\hline & & $1.1 \mathrm{~ns}$ & & & & $25 \mathrm{~ns}$ & & \\
\hline Materials & $\begin{array}{c}\text { Incident } \\
\text { fluence at } \\
\text { focus } \\
\left(\mathrm{J} / \mathrm{cm}^{2}\right)\end{array}$ & $\begin{array}{c}\mathrm{SBS} \\
\text { reflectance } \\
R_{\mathrm{SBS}} \\
(\%)\end{array}$ & $\begin{array}{l}\text { Damage } \\
\text { threshold } \\
\left(\mathrm{J} / \mathrm{cm}^{2}\right)\end{array}$ & $\begin{array}{c}\text { Incident } \\
\text { energy } \\
E_{\text {in }} \\
(\mathrm{mJ})\end{array}$ & $\begin{array}{c}\text { Incident } \\
\text { fluence at } \\
\text { focus } \\
\left(\mathrm{J} / \mathrm{cm}^{2}\right)\end{array}$ & $\begin{array}{c}\mathrm{SBS} \\
\text { reflectance } \\
R_{\mathrm{SBS}} \\
R(\%)\end{array}$ & $\begin{array}{l}\text { Damage } \\
\text { threshold } \\
\left(\mathrm{J} / \mathrm{cm}^{2}\right)\end{array}$ & $\begin{array}{c}\text { Damage } \\
\text { threshold by } \\
\text { scaling low. } \\
\left(\mathrm{J} / \mathrm{cm}^{2}\right)\end{array}$ \\
\hline FK-5 & 26.5 & & 26.5 & 30 & 185 & 22 & 144 & 135 \\
\hline BK-7 & 24 & & 24 & 33 & 205 & $46 \pm 6$ & $110 \pm 12$ & 120 \\
\hline KF-6 & 19 & & 19 & $36 \pm 4$ & $220 \pm 20$ & 65 & 77 & 95 \\
\hline LF-1 & 15 & 0 & 15 & 34 & 210 & 88 & 25 & 75 \\
\hline LF-2 & 15 & & 15 & 33 & 205 & 88 & 25 & 75 \\
\hline LLF-1 & 13.5 & & 13.5 & $23 \pm 3$ & $140 \pm 15$ & 40 & $84 \pm 9$ & 68 \\
\hline SF-6 & 8.5 & & 8 & 12 & 75 & 32 & 51 & 40 \\
\hline Fused-silica & 28 & 0 & 28 & $\begin{array}{c}90 \sim \\
\text { (no damage) }\end{array}$ & 555 & 90 & 56 & 135 \\
\hline LG-760 & 25 & & 25 & $54 \pm 4$ & $335 \pm 25$ & 40 & $200 \pm 20$ & 120 \\
\hline
\end{tabular}

スからパルス幅の平方根比例則 (熱的破壊) ${ }^{20)} に よ り$ 求め た值 $120 \pm 10 \mathrm{~J} / \mathrm{cm}^{2}$ とほぼ同じ值を示した。また, SF-6の場 合, 損傷が発生した入射エネルギー $12 \mathrm{~mJ}$ とSBS反射率 $32 \%$ より,ガラス内部に集光されたレーザーフルエンスは51J/ $\mathrm{cm}^{2}$ (比例則值 $40 \pm 4 \mathrm{~J} / \mathrm{cm}^{2}$ ) である。石英ガラスは入射エネ ルギー90mJまで増加したが内部損傷は観測されず, SBS反 射率 $90 \%$ よ求めた内部レーザーフルエンスは $56 \mathrm{~J} / \mathrm{cm}^{2}$ と なり,パルス幅比例則值 $135 \mathrm{~J} / \mathrm{cm}^{2}$ に比べ約 $1 / 2$ 以下であり,内 部損傷は発生しない.

光学ガラスの非線形屈折率 $n_{2}$ に対するパルス幅 $1.1 \mathrm{~ns}$ お よび25nsのレーザー損傷しきい值の関係をFig.4に示す. 非線形屈折率 $n_{2}$ の小さい $\left(\right.$ 約 $\left.1 \times 10^{-13} \mathrm{esu}\right)$ 光学ガラスは, 高 いレーザー損傷しきい值を示す。一方, フリント系光学ガ ラスのSF-6は, 非線形屈折率 $n_{2}$ が大きい $\left(\right.$ 約 $\left.6 \times 10^{-13} \mathrm{esu}\right)$ た め, 損傷しきい值は $8 \pm 1 \mathrm{~J} / \mathrm{cm}^{2}$ となった．実験結果より求め た経験式を(5)式に示す。

$$
\begin{array}{ll}
\mathrm{DT}_{(1 . \mathrm{nns})}=(28 \pm 3) \cdot n_{2}^{-0.7} & \left(\mathrm{~J} / \mathrm{cm}^{2}\right) \\
\mathrm{DT}_{(25 \mathrm{~ns})}=(135 \pm 14) \cdot n_{2}^{-0.7} & \left(\mathrm{~J} / \mathrm{cm}^{2}\right)
\end{array}
$$

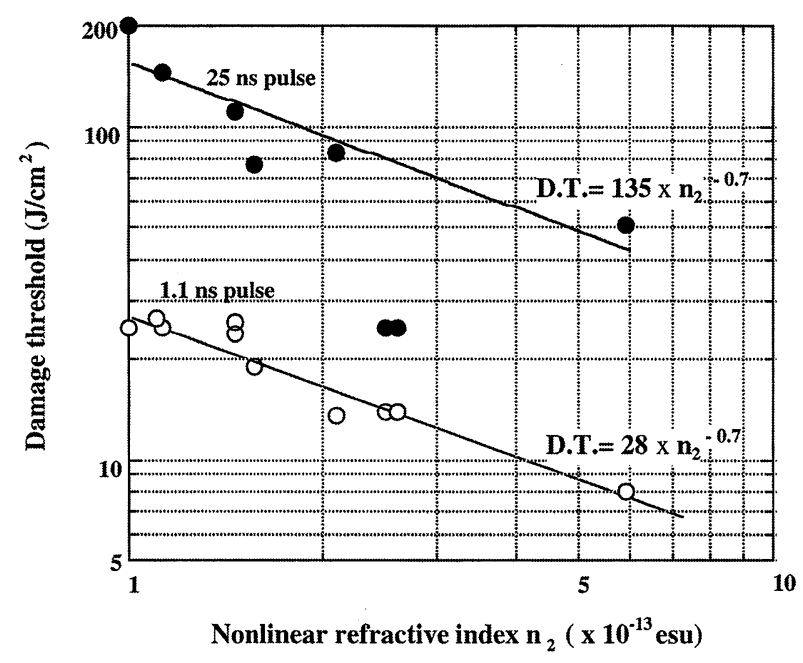

Fig.4 Laser induced damage threshold as a function of nonlinear refractive index for optical glasses at pulse width of $1.1 \mathrm{~ns}$ and $25 \mathrm{~ns}$.
この現象は, ガラス内部ヘレーザー光を集光した場合, ガ ラス内部集光点付近の屈折率はレーザー強度によって変 化する。すなわち, 自己収束効果を引き起こすため, ガラ ス内部の集光強度が増加し, レーザー損傷が発生する，ガ ラス内部の自己収束が発生する臨界パワー $P_{\text {self }}$ は,

$$
P_{\mathrm{self}}=\frac{3.77 \cdot c \cdot \lambda^{2}}{32 \cdot \pi \cdot n_{2}}
$$

となる21)。ここで, $c$ は光速 $(\mathrm{cm} / \mathrm{s}), \lambda$ は励起波長 $(\mathrm{cm})$ と $n_{2}$ は非線形屈折率 (esu)である。もし,レーザー光パワーが臨 界パワーより小さいならば,レーザー損傷しきい值測定は 自己収束の影響はない. 非線形屈折率 $n_{2}$ の小さい石英ガラ スの自己収束臨界パワー $P_{\text {self }} 1080 \mathrm{~kW}$ に対し, $n_{2}$ の大きいSF6では $181 \mathrm{~kW}$ となり約 $1 / 6$ あ゙あ。

実験経験式 (4)および(5)より,材料の非線形屈折率 $n_{2}$ と SBS発生しきい值およびレーザー損傷しきい值は密接に関 係し,指数係数はほぼ同じである。このため, 非線形屈折率 $n_{2}$ の大きいSF-6は, SBS発生しきい值は小さいがレーザー耐 力が低いため, 高出力動作には不向きである. 一方, 石英や フリント系ガラスは, SBS発生しきい值は大きいが, 高い SBS反射率が得られれば, 等価入力で極めて高い入射エネル ギーまで使用できる有望な位相共役鏡用SBS媒質である.

\section{3. 光学ガラスへの入射可能エネルギーの評価}

3.1 集光レンズによるレーザー損傷と入射エネルギー SBS利得の異なる光学ガラスにおいて, 集光レンズの焦 点距離と入射可能なエネルギー (レーザー損傷しきい值)に ついて検討した.SF-6と石英ガラスの場合, 入射エネル ギーとSBS反射率を考慮した透過エネルギーの関係をFig.5 に示す. 光学ガラスの損傷しきい值フルエンスは, レンズ のスポット径に依存しないと仮定した。 また, 透過エネル ギーはSBS反射率に依存するが, 飽和反射率以降の透過工 ネルギーは入射レーザーのビーム品質や材料の吸収係数

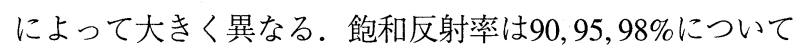
予想した。材料は透過レーザーフルエンスが損傷しきい 值を上回った時, 破壊するとした.

SF-6のレーザー損傷しきい值（パルス幅 $25 \mathrm{~ns}$ ) は約40J/ 


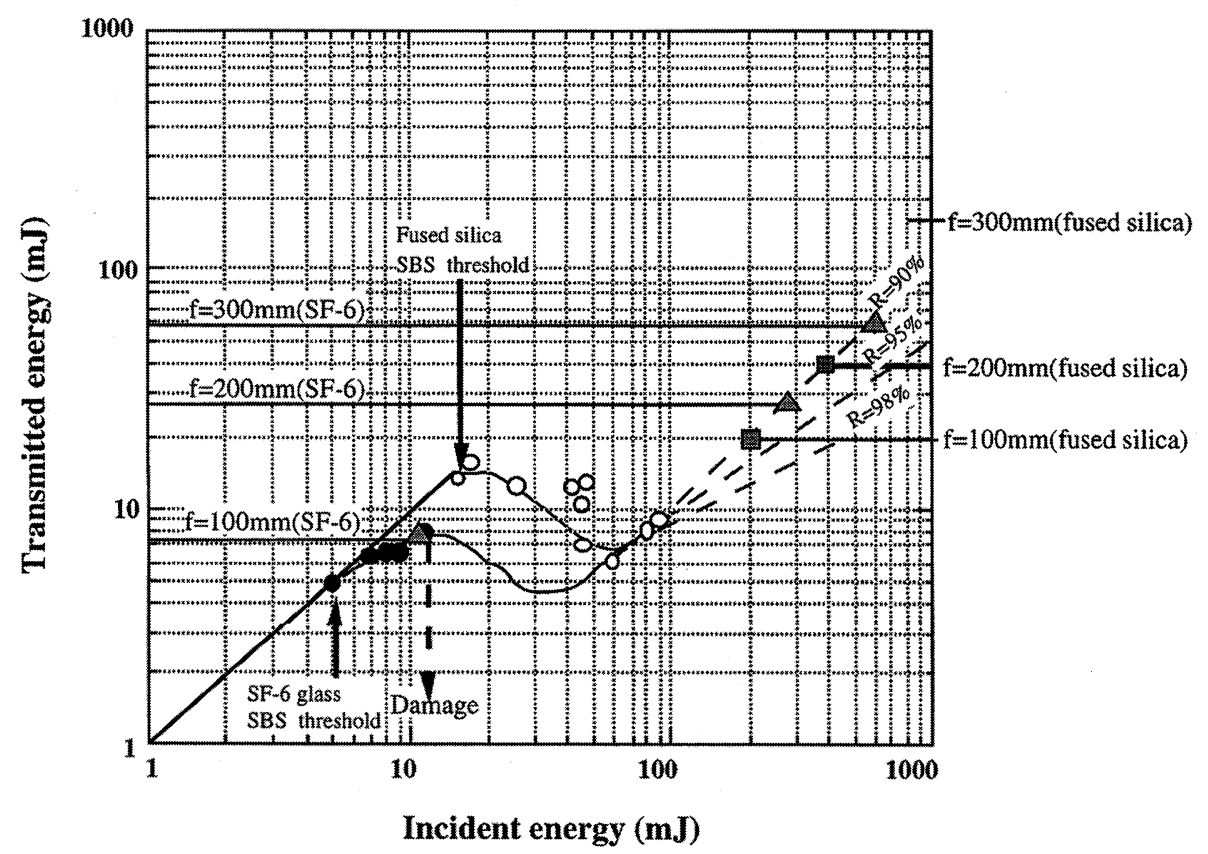

Fig.5 The transmitted energy as a function of the incident energy for a SF-6 glass and a fused silica glass.

$\mathrm{cm}^{2}$ であり, 焦点距離 $f=100 \mathrm{~mm}$ を使用すると, 入射エネル ギー約 $10.8 \mathrm{~mJ}$ の時SBS反射率 $40 \%$ 以下では内部損傷が発生 することになる。実験結果においても入射エネルギー約 $10.5 \mathrm{~mJ}$ の時SBS反射率 $30 \%$ で内部損傷が発生した。しかし ながら, SBS反射率が $90 \%$ 以上得られたならば, $f=200 \mathrm{~mm}$ 集光レンズで約 $230 \mathrm{~mJ}, f=300 \mathrm{~mm}$ では約 $600 \mathrm{~mJ}$ まで入射可 能である。一方, 石英ガラスの内部損傷しきい值を約130J/ $\mathrm{cm}^{2}$ とすると, $f=100 \mathrm{~mm}$ レンズの透過損傷エネルギーは約 $20 \mathrm{~mJ}$ であり, SBS反射率が $90 \%$ 以上の時, 入射可能なエネル ギーは約 $200 \mathrm{~mJ}$ である。実験結果では最大入射エネルギー $90 \mathrm{~mJ}$ の時, 内部損傷は発生しなかった。飽和反射率 $90 \%$ 以 上の場合, $f=200 \mathrm{~mm}$ 集光レンズでは約 $500 \mathrm{~mJ}, f=300 \mathrm{~mm}$ で

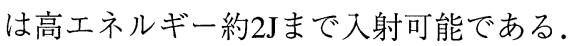

入射エネルギーを増加すると高いSBS反射率が得られる 結果, 損傷は透過エネルギー強度が材料固有の内部損傷し きい值を上回った時に発生する.SBS反射率特性は励起 レーザーのコヒーレント長が十分大きい(スペクトル幅が 十分狭い)場合, 集光レンズの焦点距離に依存しないため, 焦点距離を長くとることで集光強度を抑制できることか ら，内部損傷も発生せず高いSBS反射率が期待できる。 よって, 集光強度を抑制することにより, SF-6は低いSBS発 生しきい值から, 低入力動作が可能であり, 石英やフリン ト系ガラスは高い内部損傷しきい值から, 高い入力エネル ギーで動作可能なSBS媒質である。

\section{2 固体材料の熱レンズ効果と入射エネルギー}

固体媒質を用いたSBS発生では, 単一ショットでの入射 エネルギー制限 (レーザー損傷の発生) 以外に, レーザー光 の吸収による熱効果により,レーザービームの熱拡散およ び集束効果を発生する。このため, 集光強度が変化し入射 可能なパワーが制限される。液体やガス媒質では温度差 による媒質の対流や乱流が発生するため, 集光スポットの 分離により,位相が時間的に固定されず反射率の变動㧍よ
び忠実度が低下する22)。一方, 固体もまた吸収による温度 分布発生は避けられないが, 対流や乱流は発生せず, 集光 スポットの分離はみられない.

熱効果は単一横モードパルスを屈折率温度係数 $\mathrm{d} n / \mathrm{d} T$ が 負の媒質に入射した場合, 熱効果によりレンズの回折限界 集光スポット径でのエネルギー強度が $1 / 2$ に減少するとき の過渡的な熱的発散する臨界エネルギー $P_{\mathrm{cr}}$ によって特徵 づけられる。臨界エネルギー23)は,

$$
P_{\mathrm{cr}}=\frac{2 \pi \cdot \rho \cdot c}{\left|\frac{\mathrm{d} n}{\mathrm{~d} T}\right| \cdot \alpha \cdot\left(\frac{2 \pi}{\lambda}\right)^{2}}
$$

で表される。ここに, $\rho, c, \alpha, T, n, \lambda$ はそれぞれ媒質の密 度, 比熱, 吸収係数, 温度, 屈折率扮よび励起波長である。

レーザービームの熱的発散は $P_{\mathrm{cr}}$ 以下の入射エネルギー に対して無視できる．ところが繰り返しレーザー光をSBS 媒質に入射させた場合, 媒質内での蓄熱効果によって熱的 発散㧍よび収束が生じる。言い換えれば, 集光点のウエス 卜を熱拡散時間 $\tau$ 中に透過する全エネルギーが $P_{\mathrm{cr}}$ 以下であ れば熱的影響は無視できる. 屈折率温度係数 $\mathrm{d} n / \mathrm{d} T$ が正の 媒質である光学ガラス等の場合は, 熱的収束効果を引き起 こす．光学ガラス,レーザーガラス㧍よびレーザー結晶の 熱的物理定数と臨界エネルギー $P_{\mathrm{cr}}$ をTable 3 に示す. 石英 ガラス拉よびクラウン系ガラスは波長 $1.06 \mu \mathrm{m}$ での吸収係 数 $\alpha$ は約 $10^{-3} \sim 10^{-4} \mathrm{~cm}^{-1}$ オーダーであり, 臨界エネルギー $P_{\mathrm{cr}}$ は石英ガラス約8.3J, FK-5約5.2J, BK-7約2Jである。一方, フ リント系ガラスSF-6の波長 $1.06 \mu \mathrm{m}$ での吸収係数 $\alpha$ は約 $1 \times$ $10^{-2} \mathrm{~cm}^{-1}$ であり, 臨界エネルギーは $250 \mathrm{~mJ}$ 程度である。 FK5拉よび一部のレーザーガラスは $\mathrm{d} n / \mathrm{d} T$ が負であるため, 熱 拡散を引き起こす，石英ガラスやクラウンガラスの臨界 エネルギーは, 高平均出力レーザー用液体SBS媒質である FC-72,75の臨界エネルギー值3Jとほほ同等である。実験に 使用した $f=150 \mathrm{~mm}$ のレンズの焦点スポット径の 2 乗約 4.2 
Table 3 Thermal critical energy of several solid materials.

\begin{tabular}{|c|c|c|c|c|c|c|c|c|}
\hline Materials & $\begin{array}{c}\text { Refractive } \\
\text { index } n \\
\text { (at } 1.06 \mu \mathrm{m})\end{array}$ & $\begin{array}{l}\text { Density } \\
\rho(\mathrm{g} / \mathrm{cc})\end{array}$ & $\begin{array}{c}\text { Specific heat } \\
c(\mathrm{~J} / \mathrm{gK})\end{array}$ & $\begin{array}{c}\text { Thermal } \\
\text { conductivity } \\
(\mathrm{W} / \mathrm{cmK})\end{array}$ & $\begin{array}{c}\mathrm{d} n / \mathrm{d} T \\
\left(\times 10^{-6} / \mathrm{K}\right)\end{array}$ & $\begin{array}{c}\text { Absorption } \\
\text { coefficient } \\
\alpha\left(\mathrm{cm}^{-1}\right) \\
\text { (at } 1.06 \mu \mathrm{m})\end{array}$ & $\begin{array}{l}\text { Thermal } \\
\text { diffusion } \\
\left(\mathrm{cm}^{2} / \mathrm{s}\right)\end{array}$ & $\begin{array}{l}\text { Critical } \\
\text { energy } \\
P_{\text {cr }}(\mathrm{J})\end{array}$ \\
\hline Fused-silica & 1.45 & 2.2 & 0.840 & $14 \times 10^{-3}$ & 1.0 & $4 \times 10^{-4}$ & $7.3 \times 10^{-3}$ & 8.3 \\
\hline FK-5 & 1.487 & 2.45 & 0.808 & $9.2 \times 10^{-3}$ & -1.7 & $4 \times 10^{-4}$ & $4.7 \times 10^{-3}$ & 5.2 \\
\hline BK-7 & 1.517 & 2.51 & 0.858 & $11.1 \times 10^{-3}$ & 2.4 & $8 \times 10^{-4}$ & $5.2 \times 10^{-3}$ & 2 \\
\hline BK-7W & 1.517 & 2.52 & 0.858 & $11.1 \times 10^{-3}$ & 2.4 & $8 \times 10^{-4}$ & $5.2 \times 10^{-3}$ & 2 \\
\hline LF-1 & 1.573 & 3.16 & $(0.657)$ & $\left(8.7 \times 10^{-3}\right)$ & 1.6 & $4 \times 10^{-3}$ & $4.1 \times 10^{-3}$ & 0.58 \\
\hline LF-2 & 1.58 & 3.22 & $(0.657)$ & $\left(8.7 \times 10^{-3}\right)$ & 1.6 & $8 \times 10^{-3}$ & $4.1 \times 10^{-3}$ & 0.30 \\
\hline LLF-1 & 1.548 & 2.94 & - & - & 2.1 & $1.6 \times 10^{-3}$ & - & - \\
\hline KF-6 & 1.517 & 2.67 & $(0.754)$ & $9.5 \times 10^{-3}$ & 2.7 & $2 \times 10^{-3}$ & $4.7 \times 10^{-3}$ & 0.67 \\
\hline SF-6 & 1.805 & 5.18 & 0.389 & $10.9 \times 10^{-3}$ & 7.2 & $2 \times 10^{-3}$ & $5.4 \times 10^{-3}$ & 0.25 \\
\hline ED-2* & 1.561 & 2.54 & 0.92 & $13.5 \times 10^{-3}$ & 2.9 & & $5.8 \times 10^{-3}$ & 1.4 \\
\hline LSG-91H* & 1.550 & 2.81 & 0.63 & $10.3 \times 10^{-3}$ & 1.6 & & $5.8 \times 10^{-3}$ & 2 \\
\hline HAP-4* & 1.533 & 2.70 & 0.71 & $10.2 \times 10^{-3}$ & 1.8 & $1 \times 10^{-3}$ & $5.3 \times 10^{-3}$ & 0.5 \\
\hline LG-760* & 1.508 & 2.60 & 0.57 & $6.0 \times 10^{-3}$ & -6.8 & $1 \times 10^{-3}$ & $4.0 \times 10^{-3}$ & 0.19 \\
\hline LHG-8* & 1.520 & 2.83 & 0.75 & $5.8 \times 10^{-3}$ & $*_{-} 5.3$ & & $2.7 \times 10^{-3}$ & 0.72 \\
\hline LHG-80* & 1.533 & 2.92 & 0.63 & $6.3 \times 10^{-3}$ & -3.8 & & $3.4 \times 10^{-3}$ & 0.87 \\
\hline YAG* & 1.81 & 4.55 & 0.58 & $130 \times 10^{-3}$ & 9.7 & $1 \times 10^{-2}$ & $49.3 \times 10^{-3}$ & 0.49 \\
\hline $\mathrm{Al}_{2} \mathrm{O}_{3}$ & 1.76 & 3.98 & 0.724 & $420 \times 10^{-3}$ & $1.0-1.4$ & $1 \times 10^{-2}$ & $146 \times 10^{-3}$ & 0.43 \\
\hline
\end{tabular}

*: Nd-doped glass and crystal.

$\times 10^{-5} \mathrm{~cm}^{2}$ と熱拡散係数より求めた各光学ガラスの熱拡散時 間は, 石英ガラス : $5.8 \mathrm{~ms}, \mathrm{BK}-7: 8.1 \mathrm{~ms}, \mathrm{SF}-6: 7.8 \mathrm{~ms}$ および $\mathrm{Al}_{2} \mathrm{O}_{3}: 0.29 \mathrm{~ms}$ であり,臨界エネルギー以内での最大繰り返 し数は, 石英ガラス：172Hz, BK-7: $123 \mathrm{~Hz}, \mathrm{SF}-6: 128 \mathrm{~Hz}$ よび $\mathrm{Al}_{2} \mathrm{O}_{3}: 3450 \mathrm{~Hz}$ でる.よって, 石英ガラスは, 繰り返 し数 $170 \mathrm{~Hz}$ 程度動作において集光時にSBS発生に寄与せず 透過する全エネルギー量が8J以下 (1パルス当たり47mJ)で あれば, 安定に動作すると考えられる。

\section{4. まとめ}

非晶質光学ガラスのSBS利得係数, SBS反射特性および 材料の非線形屈折率と,レーザー損傷しきい值とSBS発生 の関係を調べた。また,これら光学ガラスを用いた位相共 役鏡の入射可能パワーについて議論し, 低入力動作ではSF6フリントガラス, 高入力動作においては石英ガラスが優れ たSBS特性を示すことが分かった。

以上の研究結果は, 固体媒質としての光学ガラスは液体 やガス媒質に代わるSBS位相共役鏡として動作することを 示唆し, 非晶質光学ガラス位相共役鏡とLD励起固体レー ザーを組み合わせることにより, 小型, 高品質, 高出力固体 レーザーの実現が期待される。

\section{参考文献}

1) V. Wang and C. R. Giuliano: Opt. Lett. 2 (1978) 4.

2) A. Ashkin, G. D. Boyd, J. M. Dziedzic, R. G. Smith, A. A. Ballman,
J. J. Levinstein, and K. Nassau: Appl. Phys. Lett. 9 (1966) 72.

3) B. Y. Zeldovich, V. I. Popovichev, V. V. Ragulskii, and F. S. Faizullov: Sov. Phys.-JETP Lett. 15 (1972) 109.

4) B. Y. Zeldovich and V. V. Shunov: Sov. J. Quantum Electron. 8 (1978) 15 .

5) D. A. Rockwell: IEEE Quantum Electron. 24 (1988) 1124.

6）吉田 国雄, 吉田 英次：レーザー研究 21 (1993) 832.

7) 吉田 英次, 吉田 国雄：核融合研究 68 (1992) 235.

8) I. D. Carr and D. C. Hanna: Opt. Commun. 62 (1987) 396.

9) C. B. Dane, L. E. Zapata, and L. A. Hackel: CLEO'93 Technical Digest CWI1 (1993) 274.

10) H. J. Eichler, A. Haase, and R. Menzel: IEEE Quantum Electron. 31 (1995) 1265.

11) A. Yariv: Phys. Lett. 28 (1976) 88.

12）吉田 英次, 吉田 国雄 : レーザー研究 22 (1994) 689.

13) D. Heiman, D. S. Hamiton, and R. W. Hellwarth: Phy. Rev. B 19 (1979) 6583.

14）吉田 英次, 藤田 尚徳, 中塚 正大, 吉村 政志, 佐々木 孝友, 吉田 国雄：レーザー研究 25 (1997) 232.

15) H. Yoshida, M. Nakatsuka, H. Fujita, T. Sasaki, and K. Yoshida: Appl. Opt. 36 (1997) 7783.

16) 吉田 英次, 藤田 尚德, 山中 龍彦, 吉田 国雄 : 光学 26(1997) No.1, 31.

17) E. P. Ippen and R. H. Stolen: Appl. Phys. Lett. 21 (1972) 539.

18) G. W. Fairs, L. E. Jusinski, and A. P. Hickman: J. Opt. Soc. Am. B10 (1993) 587.

19) H. J. Eicher, R. Menzel, R. Sander, M. Schulzke, and J. Schwartz: Opt. Commun. 121 (1995) 49.

20) W. Koechner: Solid-State Laser Engineering, 2nd ed. in Springer Series 1 (1988) 540.

21) M. J. Soileau, W. E. Williams, N. Mansour, and E. W. V. Stryland: Opt. Eng. 28 (1989) 1133.

22) J. J. Ottusch, and D. A. Rockwell: Opt. Lett. 16(1991) 369.

23) N. F. Andreev, E. Khazaniv, and G. A. Pasmanik: IEEE J. Quantum Electron. QE-28 (1992) 330. 